\author{
Maria Różańska \\ Centrum Kształcenia Praktycznego, Tarnobrzeg
}

\title{
Opracowanie i wdrożenie programu pracy z uczniem zdolnym na lekcjach z podstaw przedsiębiorczości i zajęciach dodatkowych dotyczących poradnictwa zawodowego
}

\section{WSTĘP}

Rosnące zapotrzebowanie gospodarki narodowej, nauki i kultury na wysoko kwalifikowane kadry oraz towarzyszące temu upowszechnianie oświaty sprawiają, że problem indywidualizacji kształcenia zyskuje szczególną rangę społeczną.

U podstaw właściwego działania pedagogicznego, mającego za zadanie spełnianie nadziei pokładanych $\mathrm{w}$ zindywidualizowanym kształceniu młodzieży, leży umiejętność rozpoznawania przez nauczyciela intelektualnych możliwości uczniów i stosowanie takich sposobów dydaktycznych, które powodowałyby optymalny rozwój ucznia, a szczególnie zdolnego.

Poznawanie intelektualnych możliwości uczniów należy do trudnych zadań nauczyciela, tym bardziej trudno to zrobić na lekcjach, gdzie program jest szeroki, a czas ograniczony -2 godziny w procesie kształcenia.

Pomimo tych trudności udało mi się w roku szkolnym 2002/2003 wyłonić parę osób z V klasy technikum, III klasy technikum po ZSZ i z III klasy szkoły zawodowej - w Zespole Szkół Ponadgimnazjalnych $\mathrm{nr} 3$, gdzie byłam nauczycielem przedmiotu podstawy przedsiębiorczości i zarysu wiedzy o gospodarce, którzy wyróżniali się :

- $\quad$ sprawnością językową,

- wzmożoną aktywnością intelektualną,

- niezależnością, wyrażającą się w samodzielnych sądach, dotyczących konkretnie poruszanych problemów.

Pomyślałam sobie, że warto dla nich poświęcić trochę czasu i tak zrodził się pomysł opracowania $i$ wdrożenia programu pracy z uczniem zdolnym.

\section{ZALOŻENIA PROGRAMU}

Przemiany zachodzące we wszystkich dziedzinach życia wyznaczają nowe zadania szkolne, które powinny wspierać i ukierunkowywać rozwój dziecka, zachowując właściwe proporcje między wiedzą, umiejętnościami praktycznymi i autoprezentacją.

Obecna trudna sytuacja na rynku pracy, duża konkurencja wymusza, aby absolwenci szkoły potrafili rozpoznawać własne możliwości zawodowe i pokonywać trudności na rynku pracy. 
Program, który opracowałam, jest odpowiedzią na potrzebę dużej indywidualizacji procesu nauczania, spowodowanej zróżnicowanym poziomem wiedzy i umiejętności uczniów w zakresie wiedzy ekonomicznej i informatycznej.

Program jest realizowany przez cały rok. Jest skierowany dla uczniów Technikum i ZSZ realizujących program z przedmiotu podstawy przedsiębiorczości lub zarys wiedzy o gospodarce oraz uczniów, którzy spotykają się na zajęciach dodatkowych w celu pogłębienia wiedzy i umiejętności dotyczących. rynku pracy, funkcjonowania gospodarki rynkowej i poradnictwa zawodowego.

\section{CELE:}

- rozbudzenie u ucznia procesu pamięci, kojarzenia, twórczego myślenia przez wykorzystanie metody kinezjologii edukacyjnej,

- wdrażanie nauczania wielopoziomowego (wyróżnienie podstawowego zakresu materiału obowiązującego wszystkich oraz zakresu uzupełniającego przeznaczonego dla uzdolnionych),

- przyśpieszenie rozwoju intelektualnego uczniów,

- pogłębienie i poszerzenie wiedzy uczniów z zagadnień programowych i pozarogramowych,

- rozwój zainteresowań uczniów,

- przygotowanie do samodzielnej pracy, do samokształcenia w oparciu o programy komputerowe,

- wyrobienie umiejętności zastosowania wiedzy w praktyce,

- rozwijanie przedsiębiorczości,

- rozwijanie umiejętności prezentacji,

- rozwijanie umiejętności pracy w grupie,

- rozwijanie umiejętności samooceny i samokontroli.

\section{FORMY PRACY:}

Na lekcjach:

- zadawanie dodatkowych trudniejszych zadań w czasie pracy na lekcji, w czasie sprawdzianów,

- zadawanie alternatywnych prac domowych,

- wypożyczenie uczniom książek i czasopism, poszerzających wiedzę dotyczącą rynku pracy, funkcjonowania gospodarki rynkowej,

- komunikacji interpersonalnej, globalizmu,

- przygotowywanie przez uczniów kilkuminutowych referatów i opracowań na zadany temat, ciekawostek i nowości dotyczących funkcjonowania gospodarki rynkowej,

- wprowadzenie funkcji asystenta,

- przygotowywanie i prowadzenie przez uczniów fragmentów lekcji,

- zaangażowanie uczniów zdolnych do pomocy uczniom słabszym.

Na zajęciach pozalekcyjnych:

- zapoznanie uczniów z metodą kinezjologii edukacyjnej - ćwiczenia integrujące pracę lewej i prawej półkuli mózgu, dające możliwość pełniejszego wykorzystania umysłowego potencjału człowieka,

- uczniowie pracują w 3 osobowych grupach (dobierają się sami). Grupy pracują nad zadanym zagadnieniem $\mathrm{z}$ wybranego poradnika komputerowego „Absolwent” lub 
innym wyznaczonym przez nauczyciela. Wyniki swoich prac grupa (lider grupy lub sprawozdawca) prezentuje przed całą klasą lub grupą sposób, w jaki osiągnął cel. Formułują wnioski, dokonują oceny popełnianych błędów;

- praca w grupach odbywa się równym frontem,

- po prezentacji przez liderów grup uczniowie pod kierownictwem nauczyciela wybierają najskuteczniejszą metodę, formę opracowania, spełniającą założony cel,

- forma indywidualnej pracy. Każdy uczeń realizuje oddzielne zadanie (przydzielone przez nauczyciela, wybrane przez siebie, bądź zaproponowane przez zespół). Nauczyciel tylko inspiruje, ukierunkowuje i doradza uczniom;

- metody aktywizujące: burza mózgów, drzewko decyzyjne, debata, konkurs, projekt.

\section{Procedury OSIĄGANIA CELÓW:}

- Praktyczne wykorzystanie komputera,

- Rozpoznawanie własnych możliwości zawodowych,

- Pełniejsze wykorzystanie potencjału umysłu,

- Przygotowywanie dokumentów niezbędnych do poszukiwania pracy,

- Poszukiwanie pracy,

- Przeprowadzenie rozmowy kwalifikacyjnej,

- Napisanie własnego ogłoszenia prasowego o poszukiwaniu pracy,

- Prezentowanie swoich zainteresowań, osiągnięć, mocnych i słabych stron,

- Sporządzanie dodatkowych środków dydaktycznych,

- Stworzenie narzędzi, służących do sprawdzania wiedzy i umiejętności uczniów,

- Prezentowanie form przeciwdziałania bezrobociu,

- Korzystanie z przepisów prawa pracy,

- Przygotowanie biznesplanu.

\section{Material naUCZania}

Na lekcjach:

Treści o wyższym stopniu trudności.

Na zajęciach pozalekcyjnych:

Treści uzupełniające i rozszerzające programowy materiał nauczania oraz zagadnienia interesujące uczniów.

\section{Planowane OSIĄGNięcia UCZniów}

Uczeń nabywa umiejętności :

- lepszego przyswajania nowej wiedzy i jej wykorzystania,

- sprawniejszego funkcjonowania w sytuacjach stresu,

- lepszej koncentracji,

- poprawę pamięci wzrokowej, słuchowej i ruchowej,

- formułowania i rozwiązywania problemów,

- stosowania prostych programów komputerowych symulacyjnych przebieg różnych zjawisk,

- pozyskiwania, gromadzenia i wykorzystywania informacji z różnych źródeł,

- komunikowania się za pomocą sieci Internet,

- interpretowania podstawowych przepisów prawa pracy, 
- niewerbalnego komunikowania się,

- przewidywania, formułowania i weryfikacji hipotez,

- opracowywania dokumentacji niezbędnej do poszukiwania pracy w zależności od charakteru pracy i stanowiska,

- opracowywania biznesplanów,

- opracowywania ofert, ogłoszeń,

\section{KONSPEKTY}

Przykładowe konspekty, zadania, testy.

\section{SPOSOBY EWALUACJI:}

- obserwacja,

- ankieta,

- rozmowy $\mathrm{z}$ rodzicami.

- testy.

\section{WDRAŻANIE PROGRAMU}

$\mathrm{Na}$ lekcjach wdrażałam ten program poprzez kształcenie wielopoziomowe. Wyróżniłam podstawowy zakres materiału obowiązującego wszystkich oraz zakres uzupełniający dla wyodrębnionej grupy młodzieży uzdolnionej.

Młodzież o wyższym poziomie intelektualnym dostawała do domu opracowanie zadań problemowych, które prezentowała na lekcjach pozostałym uczniom. Angażowałam również uczniów zdolnych do pracy z uczniami słabszymi, których niestety jest u nas większość.

W ten sposób rozwinęłam zainteresowanie młodzieży tematyką przedsiębiorczości, rynkiem pracy, biznesem, problemami ekonomicznymi w skali „makro”, że nie sposób było to zrealizować na jednostce lekcyjnej.

Zorganizowałam zajęcia dodatkowe dla osób zainteresowanych powyższą tematyką. Najpierw spotykaliśmy się raz w miesiącu, później co dwa tygodnie.

Chcąc bardziej zainteresować młodzież, wprowadziłam na tych zajęciach ćwiczenia integrujące pracę lewej i prawej półkuli mózgu, dające możliwość pełniejszego wykorzystania umysłowego potencjału człowieka. Zastosowałam metodę kinezjologii edukacyjnej.

Zajęcia prowadziłam w grupach metodami aktywizującymi: burza mózgów, drzewko decyzyjne, debata, projekt. Grupy pracowały nad konkretnym zagadnieniem w oparciu o program komputerowy „Absolwent”, lub inne materiały. Młodzież bardzo angażowała się do pracy w grupach. Lider grupy prezentował stanowisko grupy, wyniki prac oraz sposób, w jaki osiągnięto zamierzone efekty. Wywiązywała się dyskusja i pod moim ukierunkowaniem młodzież dokonywała oceny, formułowała wnioski. Młodzież prezentowała swój pogląd na tematy trudne nurtujące gospodarkę i rynek pracy. Np. „Sposoby rozwiązywania bezrobocia”, „Rynek unijny - szansą dla młodych Polaków” i inne dotyczące poszukiwania pracy.

Dzięki zastosowaniu ćwiczeń z zakresu kinezjologii edukacyjnej i poznaniu mechanizmów ich oddziaływania oraz zastosowania metod aktywizujących na lekcjach z podstaw przedsiębiorczości, zarysu wiedzy o gospodarce i zajęciach dodatkowych uczniowie nabyli dodatkowe umiejętności związane z lepszym przyswajaniem nowej wiedzy i jej wykorzystanie, lepszą koncentracją, poprawą pamięci wzrokowo-słuchowej i ruchowej, formułowania 
i rozwiązywania problemów, przewidywania i weryfikacji hipotez, opracowywania różnych dokumentów, niezbędnych w poszukiwaniu pracy. Poprzez stosowanie i rozwiązywanie różnych testów badali swoje predyspozycje zawodowe, które miały wpływ na wybór ścieżki zawodowej lub kierunku dalszego kształcenia. W ramach zajęć organizowałam spotkania $\mathrm{z}$ maklerem, który zapoznał młodzież z sytuacją na rynku kapitałowym. Brałam udział z młodzieżą w zajęciach prowadzonych przez doradców zawodowych w Centrum Informacji i Planowania Kariery Zawodowej w Tarnobrzegu, w seminariach prowadzonych przez Tarnobrzeską Agencję Rozwoju Regionalnego.

\section{WNIOSKI}

Na rzeczywiste efekty pracy na polu rozwijania uzdolnień uczniów trzeba jeszcze poczekać, ale już teraz za swój sukces uważam samozatrudnianie się młodzieży, zakładanie swoich firm, które pomimo dużej konkurencji usiłują działać na tym trudnym rynku, jaki panuje w mieście i okolicy.

Opracowanie tego programu i jego wdrażanie dało mi dużą satysfakcję, gdyż w ten sposób inspirowałam uczniów zdolnych do aktywności twórczej i oryginalnego myślenia. Wielu z nich wybrało studia ekonomiczne, a część absolwentów ZSZ kontynuuje naukę w technikum budowlanym.

Wykorzystują oni często dotychczas zdobyte umiejętności z zakresu wiedzy zawodowej i ekonomicznej poprzez świadczenie usług na rzecz podmiotów gospodarczych i osób prywatnych. Często ich spotykam. pracują na różnych stanowiskach, rozmawiamy, wspominamy, dzielimy się doświadczeniami, chwalą się swoimi sukcesami, czasami porażką na tym niezbyt uczciwym rynku pracy, proszą o rady.

Uwzględniając to, że młodzież ta pochodzi w większości z rodzin średniozamożnych, a często po prostu z biednych, jest to ich sposób na życie. Pracując, pokrywają koszty nauki, a często i utrzymania, ale nie załamują się, myślą o studiach i mam nadzieję, że równie dobrze sprawdzą się w przyszłości na odpowiedzialnych stanowiskach.

Program pracy z uczniem zdolnym można wykorzystać również na zajęciach dodatkowych z orientacji i poradnictwa zawodowego. 